\title{
The Impact of Socio-Economic Characteristics on Coffee Farmers' Marketing Channel Choice: Evidence from Villa Rica, Peru
}

\author{
Angie Higuchi (Corresponding author) \\ Graduate School of Bio-resource and Bio-environmental Science \\ Seminar of Food Marketing, Department of Agricultural and Resource Economics \\ Faculty of Agriculture, Kyushu University 6-9-1 Hakozaki \\ Higashi-ku, Fukuoka 812-8581, Japan \\ Tel: 81-926-422-976 E-mail: angiehiguchi@gmail.com \\ Masahiro Moritaka \\ Faculty of Agriculture, Kyushu University \\ Seminar of Food Marketing, Department of Agricultural and Resource Economics \\ Faculty of Agriculture, Kyushu University 6-9-1 Hakozaki \\ Higashi-ku, Fukuoka 812-8581, Japan \\ Tel: 81-926-422-976 E-mail: m-moritaka@agr.kyushu-u.ac.jp \\ Susumu Fukuda \\ Faculty of Agriculture, Kyushu University \\ Seminar of Food Marketing, Department of Agricultural and Resource Economics \\ Faculty of Agriculture, Kyushu University 6-9-1 Hakozaki \\ Higashi-ku, Fukuoka 812-8581, Japan \\ Tel: 81-926-422-976 E-mail: sufukuda@agr.kyushu-u.ac.jp
}

Received: October 31, $2011 \quad$ Accepted: November 28, $2011 \quad$ Published: February 1, 2012

doi:10.5539/sar.v1n1p13

URL: http://dx.doi.org/10.5539/sar.v1n1p13

\begin{abstract}
Villa Rica is one of the most important coffee-producing districts in Peru. In Villa Rica there are several marketing channels: intermediaries, private companies, cooperatives and associations. The intermediaries focus solely on higher prices while marketing organizations offer benefits to their members. The main aim of this paper is to analyze the socio-economic characteristics that influence coffee farmers to join a formal organization vs. those who distribute their product through intermediaries. A survey of 60 producers was carried out in June 2011 in Villa Rica. A binary logistic model was used in order to show how these characteristics affect farmers' choice of which marketing channel to use to distribute their product. The results demonstrated that farmers who are keen to receive technical assistance participate in the marketing organizations. These coffee marketing organizations should look for ways to improve the extension component through training and knowledge transfers to smallholder farmers.
\end{abstract}

Keywords: Socio-economic characteristics, Coffee marketing organization, Technical assistance, Logistic model, Intermediaries, Cooperative, Association, Private company

\section{Introduction}

Peru's main agricultural export item is coffee. Peru is the world's third largest coffee producer after Brazil and Colombia (Tulet, 2010), with over 160000 farming families involved in coffee production (Peruvian Ministry of Agriculture, 2011). Even though 95\% of the coffee beans production is destined for export markets, most coffee 
producers live below the poverty line and manage agro-ecosystems in some of the world's most culturally and biologically diverse regions (Bacon, 2005). Villa Rica is one of Peru's most important coffee-producing districts due to its topography and climate which are ideal for this crop. The majority of farmers in this district are financially dependent upon coffee, and they only allocate a small portion of their land to growing subsistence crops or to diversifying crop mixes (Watson \& Achinelly, 2008).

Over the past 20 years, domestic terrorist groups have frequently attacked the city of Villa Rica. Rural farmers lost their influence and found themselves isolated in the market due to the ruthless and violent tactics employed in this internal conflict. Small-scale farmers joined forces to form a union in an attempt to obtain economies of scale in marketing, pool their resources, and export their coffee (Bacon, 2005). Nevertheless, there is not a strong relationship between private coffee companies, associations, cooperatives and small-scale farmers (Yzaguirre \& Saito, 2006). Small-scale farmers' land holdings are small. As their production volume is small and they can not commercialize individually, they market their coffee via a marketing organization (cooperative, association or private company). Many of the individuals have built links with a coffee marketing organization for the purposes of obtaining cheaper inputs and obtaining better access to marketing and capital equipment. Moreover, around $65 \%$ of the coffee is commercialized by these coffee marketing organizations which teach farmers production techniques and post-harvesting management (Table 1).

In Villa Rica there are two marketing channels (Figure 1): primary, there are the intermediaries who just focus on the prices, then, there are the coffee marketing organizations who for instance, give technical assistance to their members. In turn, they are subdivided into three sub-marketing channels: first of all, the private companies who monitor cocoa beans differentiation because of their participation in the international market. These private companies are composed of large-scale farmers who have the correct machinery to dry and ferment coffee beans and meet the quality that the international market demands. Subsequently, there are the cooperatives which distribute their coffee to the national and international markets. Finally, there are the associations who also distribute their cocoa as cooperatives. There are some differences between the associations and cooperatives: the latter share the income from the sales surplus at the end of the year with its members. After selling their high quality beans to the international market, these coffee marketing organizations sell their low quality coffee beans to the national industry.

Farmers from the same district who choose intermediaries may have very different holdings, practices, demographics, or outlooks from their counterparts who choose to participate in an organization (Arnould, Plastina \& Ball, 2009). Measuring farmers' perceptions as well as studying the socio-economic characteristics and information-seeking behavior that influence those perceptions should be the preliminary step in developing extension programs to promote sustainability among farmers (Füsun Tathdil, Boz \& Tatlidil, 2009a). Therefore, it is important to understand the socio-economic characteristics to make judgments about the effects of different policies on economic welfare. The main aim of this paper is to analyze the socio-economic characteristics that influence membership in a coffee marketing organization vs. coffee farmers who distribute their product through intermediaries.

\section{Data}

A survey of the coffee producers was carried out in June 2011 in Villa Rica, Pasco (one of the largest coffee producing region in Peru). Primary data was gathered by using a structured questionnaire at the study site with the CUNAVIR cooperative and the support of the local authorities in Villa Rica. This covered topics such as the socio-economic characteristics of households and marketing information. The CUNAVIR cooperative has approximately 200 members and is currently the largest association in Villa Rica. Interviews were conducted by the CUNAVIR cooperative which collected 30 completed surveys from its members. The Villa Rica authorities also contributed to this analysis by collecting 25 completed surveys from farmers who commercialize through intermediaries and also 5 surveys from farmers who use private companies. As we want to measure which personal characteristics were important in the decision-making process about which marketing channel were chosen by small-scale farmers for commercializing their product (coffee marketing organizations vs. intermediaries), those 5 farmers who use private companies were also added to the 25 CUNAVIR members sample. Consequently, for the purposes of analysis, there are 35 farmers in this sample who participate in an organization vs. 25 farmers who commercialize their coffee through intermediaries. An interview with a local government agronomist was also considered for qualitative description purposes.

\section{Modeling Approach}

To identify the factors which make farmers choose a given marketing channel to commercialize their coffee, a bivariate logistic regression was estimated. This helps examine the effect of different household factors on 
membership in an organization or distribution of their coffee through intermediaries. As membership in a coffee marketing organization is a binary decision, a logistic model was used in order to determine what socio-economic factors influence the choice to sell coffee through a formal organization or through the intermediaries. The odds ratio related to each explanatory variable is reported in the results section, and the ratio can be interpreted as a multiplier of the odds of having the willingness to belong or not to the cooperative. If the value is greater than 1 , then it indicates that as the predictor increases, the odds of cooperative membership increase and vice-versa (Field, A., 2009). The econometric model is given in Equation 1:

$$
P(Y)=\frac{1}{1+e^{-\left(b_{0}+b_{1} X_{1}+b_{2} X_{2}+\ldots b_{i} X_{i} \ldots+b_{n} X_{n}+\mu\right)}}
$$

Using the Binary logistic regression model equation (1) for the model purposes, $\mathrm{Y}$ is the marketing channel that the farmer chooses (if $Y=1$, the farmer belongs to an organization; otherwise if $Y=0$, the farmer chose the intermediaries); $P(Y)$ is the probability of participation in a marketing channel, $\mathrm{b}_{0}$ is the intercept, $\mathrm{b}_{i}(\mathrm{i}=1 \sim \mathrm{n})$ are the estimated model coefficients; $\mathrm{x}_{i}(\mathrm{i}=1 \sim \mathrm{n})$ are the independent variables and finally, $\mu$ is a random error term. Summary statistics for the variables included in the logistic model are given in Table 2.

Peruvian coffee family plots range from 3 to 5 hectares of land (Peruvian Ministry of Agriculture, 2011). Among surveyed households, both marketing organizations' members and non members have area plants above the national average. An important reason is that Villa Rica has fertile soils and also an appropriate climate to cultivate this crop.

It is expected that farmers see a positive effect from receiving technical assistance because they participate as a member in a coffee marketing organization. Bias was controlled by not considering the marketing organization in which the farmer is currently a member as an institution that gives technical assistance to the farmers (N.instcha-1). After all, if coffee farmers belong to this institution, then they will have free access to technical assistance, which gives its members advantages compared to non members, and thus becomes a potential source of bias in this model.

Socio-economic variables are commonly used by many researchers to study the influence of different factors on the behavior of a specific group of people (Füsun Tathdil, Boz \& Tatlidi, 2009b). Socio-demographic variables such as gender, age, education and income influence people's opinions about farming (Boogard, Bock, Oosting, Wiskerke \& van der Zijpp, 2011). Previous studies about Peruvian fair trade cooperatives found that members generally plant crops in slightly larger areas, which also encourages gender equality than in non-member households (Murray, Raynolds \& Taylor, 2006a). Thus, female membership improves their process of economic development. Moreover, the more educated the farmers are, the more receptive they will be with regards to the adoption of new technologies. Nonetheless, being a member of a Peruvian cooperative for instance is not a significant predictor of education (Murray, Raynolds \& Taylor, 2006b). Farmers who are married are generally involved in an organization compared to single farmers who commercialize through the intermediaries as the former are more likely to be under pressure to produce more, not only for family consumption but also for sale (Opara, 2010). In addition, age can be considered as an indicator of experience in farming (Gebremedhin, Jaleta \& Hoekstra, 2009) which has relationship with agricultural activities because off-farm work first increases and then decreases with age (Lien, Kumbhakar \& Hardaker, 2010).

\section{Results and Discussion}

Table 3 shows the results of the logistic model. Exp (B) is the exponentiation of the B coefficient, which is an odds ratio. A correlation matrix was previously used to detect the presence of co-linearity between the explanatory variables used in the model. The variables selected for the econometric model are not highly correlated, thus avoiding potential biases in the model estimation.

Estimation results show that when the number of institutions that give technical assistance to the farmers increased by a unit, the change in the odds of membership to an organization was 9.70 ; farmers who belong to a marketing organization are concerned about their knowledge and learning sustainable techniques so as to become competitive in the market. Farmers who distribute their coffee through intermediaries, meanwhile, do not receive any exposure to alternative production technologies as it is difficult for them to exchange ideas with other group members.

As expected, being older equates to more experience in cultivating coffee. Thus, it has a positive effect on the odds of joining an organization $(\mathrm{p}<0.05)$, making it more likely to participate in market, having better farming capacity and having access to information. Likewise, the number of members in a household has a significant but negative effect $(p<0.05)$ because farmers who belong to an organization prefer to send their children to school 
instead of having them help out on the farm. Thus, part time labor is hired especially during the harvest season and adult males with less than primary school education are the most common agricultural workers (Dammert, 2007). Married members seems to be more engaged in farm work $(p<0.05)$ than non-members. The reason for this could be that the partner may choose to stay at home to care for their children, helping on the farm and also in domestic tasks. This could be an incentive to the married farmer to use agricultural information as it is their desire to produce greater quantities and better quality goods in order to obtain more income to improve their livelihoods.

\section{Conclusions}

Socioeconomic characteristics are found to be effective in predicting a farmer's marketing choice. Numerical results demonstrate that farmers who join an organization are particularly keen to gain technical assistance because they then can learn more techniques in order to improve their knowledge and improve their standard of living. Results also demonstrated that farmers who possess the following attributes were more likely to participate in an organization: 1) being older and 2) being married. Alternatively, farmers who commercialize through intermediaries require more household members to help in farm tasks.

A review of the analyzed socioeconomic features is important for farmers' organizations in order to make decisions so that they can empower themselves and encourage participation and unity among their members. Organizations should look for ways to improve the extension component so as to improve agricultural productivity through training and knowledge transfers to smallholder farmers. Moreover, compensation schemes such as the distribution of surplus income sharing among members act as an incentive to produce good quality coffee beans.

\section{Acknowledgements}

The author is deeply grateful to Villa Rica government agronomist Israel Cusi and his wife Judith Mato for helping me collecting the data that made possible this study in Villa Rica; to Dr. Adam Komarek for his priceless comments and to Severine Watson for proofing this document.

\section{References}

Arnould, E. J., Plastina, A., \& Ball, D. (2009). Does fair trade deliver on its core value proposition? Effects on income, educational attainment, and health in three countries. Journal of Public Policy \& Marketing, 28(2), 186-201. http://dx.doi.org/10.1509/jppm.28.2.186

Bacon, C. (2005). Confronting the Coffee Crisis: Can fair trade, organic, and specialty coffees reduce small-scale farmer vulnerability in northern Nicaragua?. World Development, 33(3), 497-511.

Boogaard, B. K., Bock, B. B., Oosting, S. J., Wiskerke, J. S. C., \& van der Zijpp, A. J. (2011). Social acceptance of dairy farming: The ambivalence between the two faces of modernity. Journal of Agricultural Environmental Ethics, 24(3), 259-282. http://dx.doi.org/10.1007/s10806-010-9256-4

Dammert, A. (2007). Child labor and schooling response to changes in coca production in rural Peru. Discussion Paper no. 2869. Institute for the Study of Labor (IZA).

Field, A. (2009). Discovering statistics using SPSS. ( $3^{\text {rd }}$ ed.). Sage Publications LTD, England.

Füsun Tathdil, F., Boz, I., \& Tatlidil, H. (2009). Farmers perception of sustainable agriculture and its determinants: a case study in Kahramanmaras province of Turkey. Environment, Development and Sustainability, 11(6), 1091-1106. http://dx.doi.org/10.1007/s10668-008-9168-x

Gebremedhin, B., Jaleta, M., \& Hoekstra, D. (2009). Smallholders, institutional services, and commercial $\begin{array}{lllll}\text { transformation in } \quad \text { Ethiopia. Agricultural } & \text { Economics, } & 40, & \text { 773-787. }\end{array}$ http://dx.doi.org/10.1111/j.1574-0862.2009.00414.x

Lien, G., Kumbhakar, S. C., \& Hardaker, J. B. (2010). Determinants of off-farm work and its effects on farm performance: the case of Norwegian grain farmers. Agricultural Economics, 41(6), 577-586. http://dx.doi.org/10.1111/j.1574-0862.2010.00473.x

Murray, D. L., Raynolds, L. T., \& Taylor, P. L. (2006). The future of fair trade coffee: dilemmas facing Latin America's small-scale producers. Development in practice, 16(2), 179-192. http://dx.doi.org/10.1080/09614520600562397

Opara, U. N. (2010). Personal and Socio-Economic Determinants of Agricultural Information Use by Farmers in the Agricultural Development Programme (ADP) Zones of Imo State, Nigeria. Library Philosophy and Practice. October edition. [Online] Available: http://unllib.unl.edu/LPP/opara.htm 
Peruvian Ministry of Agriculture web site (2011): http://www.minag.gob.pe

Tulet, J. (2010). Peru as a new major actor in Latin American coffee production. Latin American Perspectives, 37(2), 133-141. http://dx.doi.org/10.1177/0094582X09356962

Watson, K., \& Achinelli, M. (2008). Context and contingency: the coffee crisis for conventional small-scale coffee farmers in Brazil. The Geographical Journal, 174(3), 223-234. http://dx.doi.org/10.1111/j.1475-4959.2008.00277.x

Yzaguirre, A. M., \& Saito, I. (2006). Actores sociales y circuito del café en Villa Rica, Oxapampa. Peru Hoy, no. 10. Desco, Centro de Estudios y Promoción del Desarrollo. Peru. [Online] Available: http://desco.cepes.org.pe/apc-aa-files/d38fb34df77ec8a36839f7aad10def69/PeruHoy20006B.pdf (December 2006)

Table 1. Breakdown of coffee selling percentage by marketing channel

\begin{tabular}{|c|c|c|c|c|}
\hline \multirow{2}{*}{ Marketing channels } & \multirow{2}{*}{ Intermediaries } & \multicolumn{3}{|c|}{ Coffee marketing organizations } \\
\cline { 3 - 5 } & & Associations & Cooperatives & Private companies \\
\hline $\begin{array}{c}\text { Coffee selling in metric tons } \\
(\%)\end{array}$ & $35 \%$ & $30 \%$ & $5 \%$ & $30 \%$ \\
\hline
\end{tabular}

Source: Proamazonia, 2003

Table 2. Summary Statistics

\begin{tabular}{|c|c|c|c|c|c|c|c|}
\hline \multirow[t]{2}{*}{ Variable } & \multirow[t]{2}{*}{ Description } & \multicolumn{2}{|c|}{ Total $(n=60)$} & \multirow{2}{*}{$\frac{\text { Org member }}{\text { Mean }}$} & \multirow{2}{*}{$\begin{array}{l}(n=35) \\
S D\end{array}$} & \multicolumn{2}{|c|}{ Intermediaries $(\mathrm{n}=25)$} \\
\hline & & Mean & SD & & & Mean & SD \\
\hline Orgmembr & Member of an organization $(y e s=1, \mathrm{no}=0)$ & 0.58 & 0.50 & 1.00 & 0.00 & 0.00 & 0.00 \\
\hline N.inst-1 & No. of institutions -1 that gives Technical assistance (number) & 0.85 & 1.10 & 1.29 & 1.23 & 0.24 & 0.44 \\
\hline Coffeelnd & Coffee land (ha) & 5.34 & 8.02 & 5.21 & 6.33 & 5.52 & 10.08 \\
\hline Age & Farmer's age (years) & 47.62 & 12.86 & 50.77 & 14.18 & 43.20 & 9.32 \\
\hline Education & Education (years) & 8.87 & 3.78 & 8.86 & 4.20 & 8.88 & 3.18 \\
\hline Fammbr & Family members that work on the farm & 4.05 & 2.00 & 3.97 & 2.01 & 4.16 & 1.97 \\
\hline Occupat & Occupation (agriculture $=1$, other $=0$ ) & 0.78 & 0.42 & 0.80 & 0.41 & 0.76 & 0.44 \\
\hline Sex & Sex $($ male $=1$, female $=0)$ & 0.88 & 0.32 & 0.86 & 0.36 & 0.92 & 0.28 \\
\hline Married & Married $($ yes $=1$, no $=0)$ & 0.80 & 0.40 & 0.83 & 0.38 & 0.76 & 0.44 \\
\hline
\end{tabular}

Table 3. Results of the binomial logistic regression model

\begin{tabular}{lllll}
\hline Variable & $\mathrm{B}(\mathrm{SE})$ & \multicolumn{3}{l}{ 95\% confidence intervals for odds ratio } \\
\hline & & Lower & Odds ratio & Upper \\
Intercept & $-4.54(2.71)^{*}$ & & 0.01 & \\
N.instcha-1 & $2.27(0.70)^{* * *}$ & 2.45 & 9.70 & 38.49 \\
Coffeelnd & $0.06(0.05)$ & 0.97 & 1.06 & 1.16 \\
Age & $0.84(0.04)^{* *}$ & 1.00 & 1.09 & 1.18 \\
Education & $0.05(0.11)$ & 0.86 & 1.06 & 1.30 \\
Famemb & $-0.52(0.25)^{* *}$ & 0.37 & 0.60 & 0.99 \\
Occup & $0.55(0.94)$ & 0.37 & 0.60 & 0.98 \\
Sex & $-1.17(1.08)$ & 0.04 & 0.31 & 2.54 \\
Married & $2.27(1.18)^{* *}$ & 0.17 & 9.68 & 97.39 \\
\hline
\end{tabular}

$\mathrm{R}^{2}=0.42$ (Cox \& Snell), 0.56(Nagelkerke), $* * * \mathrm{p}<0.10, * * \mathrm{p}<0.05, * * * \mathrm{p}<0.01$. 


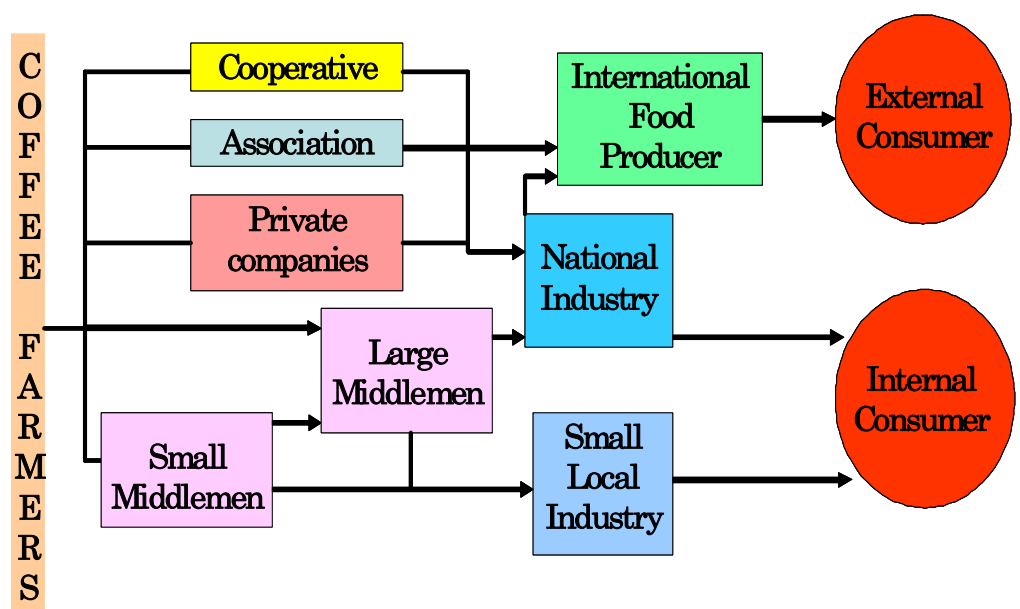

Figure 1. Peruvian coffee marketing channel

Source: Agromarketing, 2007 